\title{
Effect of IN-OVO injection with Nano Iron - Particles on Physiological Responses and Performance of Broiler Chickens under Saini Conditions
}

\author{
Dr. Amal Mohammed Hassan
}

Ass. Professor of Poultry Physiology, Animal \& Physiology Department, Desert Research Center (DRC).

\begin{abstract}
A total of 600 fertile eggs, in a completely randomized design were used to investigate the effects of Iron nano-particles IN-OVO injection on productive performance, immune status and physiological responses in broiler chickens. The eggs were divided into 6 groups that assigned as: T1 (control; without injection), T2 (injected with $0.1 \mathrm{ml}$ saline 9.0\%; sham control), T3; (injected with $0.1 \mathrm{ml}$ of 20 ppm Fe-NPs organic, T4 (injected with $0.1 \mathrm{ml}$ of 20 ppm Fe-Nano inorganic), $T 5$ (injected with $0.1 \mathrm{ml}$ of $20 \mathrm{ppm}$ $\mathrm{Fe}$ organic) and T6 (injected with $0.1 \mathrm{ml}$ of $20 \mathrm{ppm} \mathrm{Fe}$ inorganic). At $7^{\text {th }}$ day of incubation, the corresponding doses were in-ovo injected in $0.1 \mathrm{ml}$ solution into the air sac.

The results showed that: Hatchability was highly significant

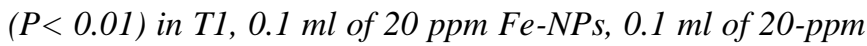
$\mathrm{Fe}$-NPs-Alimet chelate, $0.1 \mathrm{ml}$ of $20 \mathrm{ppm} \mathrm{Fe}$-Aliment chelate and $0.1 \mathrm{ml}$ of 20-ppm Fe-Aliment chelate. The egg weight was higher $(P<0.01)$ in T2. There was an increase $(P<0.01)$ in chick weight in controls, other Fe-NPs organic or Fe-NPsinorganic and $\mathrm{Fe}$ organic in comparison with other treatments. In addition, chick body weight to egg weight ratio in controls, Fe-Nano organic and FeNPs- inorganic was higher $(P<0.01)$ than in the other groups. T3 has shown the highest $(P<0.01)$ relative weight compared to the other treatments. Serum Fe content and liver function were $(P<$ 0.01) higher in by using Fe-NPs, Fe-NPs alimet inorganic and Fe-organic than other treatments. The treatments of $\mathrm{Fe}$ NPs- organic and Fe-Aliment chelate, chickens' blood hemoglobin increased significantly compared with the other treatments. These results suggest that Fe-NPs, Fe-NPsAlimet chelate and Fe-Alimet chelate improved embryonic growth and development.
\end{abstract}

Keywords- Broiler chicken, hatchability, in- ovo, iron nano-particles, immunity.

\section{INTRODUCTION}

Minerals play a vital role for maintaining homeostatic conditions in living organisms. Nanotechnology (the use of nano-particles of diameters between 1 and $100 \mathrm{~nm}$ ) is nowadays applied in science, engineering, and agriculture (Scott and Chen, 2002 and Oberdorster and Donaldson, 2007). Nano-particles activities depend on their physical and chemical characteristics. Nanoparticles can show unique biological behavior, yet, the main mechanism of their action is still unknown (Shimizu, et al., 2009). These particles have features, such as large surface area (increasing physical, chemical, and biological activities) and higher solubility and mobility (Dimanet al., 2018 and Toyooka, et al., 2009). High surface to volume ratio allows the functionalizing of nanoparticles with different ligands, coatings and other useful tools for lots of biomedical applications. High surface to volume ratio allows the functionalizing of nanoparticles with different ligands, coatings and other useful tools for lots of biomedical applications. Thus, it allows the functionalizing of nanoparticles with different ligands, coatings and other useful tools for lots of biomedical applications. However, the new physical and chemical properties of novel engineered nanoparticles make them extremely attractive for use in applications like medical sciences (Park, et al., 2010). Nano-particles have many novel properties compared with the bulk materials. Thus, inorganic nano-particle elements are widely used to enhance the productive performance of livestock, Ma et al., (2006).

Embryonic development relays upon the availability of the required nutrients within the egg. Nutrient management inovo may provide an alternative method for poultry industry to increase hatchling weight. Chicks are affected by the nutrients in yolk remaining in the peritoneal cavity post hatching (Romanoff, 1960). Thus, a continually and precisely regulated supply of trace elements derived from stores within the egg is essential to ensure avian embryonic survival. 
However, the high-metabolic rate, fast-growing rate of chicken embryos could be liable tomineral deficiency that lead to metabolic disorders (Tonaet al., 2004).

On the other hand, embryonic development relays upon the availability of the required nutrients within the egg. Nutrient management in-ovo may provide an alternative method for poultry industry to increase hatchling weight. Chicks are affected by the nutrients in yolk remaining in the peritoneal cavity post hatching (Romanoff, 1960). Thus, a continually and precisely regulated supply of trace elements derived from stores within the egg is essential to ensure avian embryonic survival. The high-metabolic rate, fast-growing rate of chicken embryos could be liable tomineral deficiency that lead to metabolic disorders (Tonaet al., 2004).

Iron $(\mathrm{Fe})$ is essential for a variety of physiological processes in livestock (e.g. DNA synthesis, oxygen transport, etc.) as illustrated by Lozoffet al., (2006); Whitnall and Richardson, (2006) and Li and Zhao, (2009). NRC (1994) recommended 50-120 ppm daily intake of iron for poultry. Iron in the form of nano-particles has been reported to be less toxic than inorganic iron salts (Nikonovet al., 2012). Additionally, they have prolonged effects on biological activities (Kovalenko and Folmanis, 2006). Iron nanoparticles are more stable in air and have the ability to be degraded or metabolized in vivo, making them excellent candidates for a large number of applications (Bronstein et al., 2007).

Iron oxide nanoparticles (IONPs) are frequently used in biomedical applications, yet their toxic potential is still a major concern. While most studies of biosafety focus on cellular responses after exposure to nanomaterials, little is reported to analyze reactions on the surface of nanoparticles as a source of cytotoxicity. Results showed that IONPs had a concentration-dependent cytotoxicity on human glioma U251 cells, and they could enhance $\mathrm{H}_{2} \mathrm{O}_{2}$-induced cell damage dramatically. However, many studies have been conducted to evaluate the potential toxicity of iron oxide nanoparticles, Das, et al., (2007).

The goal of present study was to investigate the effects of in- ovo injection of iron, iron nanoparticle and iron chelates nanoparticles methionine during broiler embryonic devolvement on productive performance, physiological and immunological responses and the absorption of iron.

\section{MATERIALS AND METHODS}

\section{Experimental Design and Management}

A total of 600 fertile broiler eggs obtained from cobb500 ${ }^{\mathrm{TM}}$ parent stock were randomly divided into six equal groups. Eggs were individually weighed with an average of $60.83 \pm 0.80 \mathrm{~g}$. Eggs were set in the hatchery and injection site was disinfected with ethyl alcohol, sealed with wax after injection then transferred to hatching baskets. The eggs were divided into 6 groups that assigned as: T1 (control; without injection), T2 (injected with $0.1 \mathrm{ml}$ saline 9.0\%; sham control), T3; (injected with $0.1 \mathrm{ml}$ of $20 \mathrm{ppm} \mathrm{Fe-NPs}$ organic, T4 (injected with $0.1 \mathrm{ml}$ of $20 \mathrm{ppm}$ Fe-Nano inorganic), T5 (injected with $0.1 \mathrm{ml}$ of $20 \mathrm{ppm} \mathrm{Fe}$ organic) and T6 (injected with $0.1 \mathrm{ml}$ of $20 \mathrm{ppm} \mathrm{Fe-inorganic).} \mathrm{At} 7^{\text {th }}$ day of incubation, the corresponding doses were in-ovo injected in $0.1 \mathrm{ml}$ solution into the air sac. Iron oxide nanoparticles were prepared according to Reimers and Khalafalla (2011), suspended in Kno DMEM cell culture medium and dispersed by an ultrasonic bath. The injection was performed at day 7 of incubation into the air sac. Eggs were candled on $7^{\text {th }}$ day of hatchery and $17^{\text {th }}$ day to remove infertile eggs. Aliment according to HMTBA, Novus International, Inc., Charles, MO, USA. Iron Aliment Chelate according to Predieriet al. (2005), Fe-Nano Alimet Chelate Based on Marinescu et al. (2006).

Post- hatch, a total number of 360 one-day-old chicks were randomly distributed into six equal| $(\mathrm{n}=60$ / treatment $)$ groups with three replicates ( 20 chicks/ each) according the corresponding treatments.

Experimental chicks were kept under similar managerial, hygienic and environmental conditions. The chicks were housed in cages from hatch up to 5 weeks of age. Average of indoor ambient temperature (AT, ${ }^{\circ} \mathrm{C}$ ) and Relative Humidity (RH, \%) were recorded using electronic digital thermo-hygrometer. Average of AT and RH was 35.7 $\pm 0.98^{\circ} \mathrm{C}$ and $24.2 \pm 1.32 \%$, respectively. Feed was offered ad libitum according to NRC (1994) recommendations. Fresh water was made available all the daytime. Live body weight and feed intake were recorded weekly before offering feed. At the end of the trial, five broiler chicks from each group were picked randomly for blood sampling.

Blood samples $(n=30)$ were randomly withdrawn from 5 chicks immediately before slaughtering of chicks (at day 35) from the (brachial) wing vein into tubes containing EDTA as anticoagulant and centrifuged at $3000 \mathrm{rpm}$ for 20 minutes for the separation of plasma and kept at $\left(-20^{\circ} \mathrm{C}\right)$ until further analysis.

Experimental traits:

1. Hatchability percentage and ratio of chick weight to egg weight.

2. Weekly body weight, body weight gain, feed consumption and feed conversion ratio.

3. Hematological parameters: Red blood cells count, and hemoglobin concentration were measured immediately after blood collection. 
4. Blood metabolites: Total protein (TP), albumin (AL), total lipids (TL), Triglycerides (Tg), cholesterol, iron, TIBC and ferritin, liver enzymes (alanine transaminase (ALT), aspartic transaminase (AST)), plasma immunoglobulin IgG and IgM concentration, creatinine $(\mathrm{Cr})$ and globulin and albumin ratio $(\mathrm{A} / \mathrm{G}$ ratio) were calculated. Blood metabolites were determined calorimetrically by using commercial kits (Bio Systems S.A. Costa Brava 30, Barcelona. Spain, Barcelona).

5. Blood hormones: Triiodothyronine (T3) hormoneswas measured by ELISA technique using IMMUNOSPEC kits supplied by (Immunospec Corporation, 7018 Owensmounth Ave. Suite 103 Canoga Park, CA 91303, USA).

Statistical analysis was carried out using General Linear Model (GLM) procedures by SAS (2010) using simple oneway analysis of variance. Significant differences among treatment groups were tested using Duncan's multiple range tests, Duncan, (1955).

\section{RESULTS AND DISCUSSION} Effect of ovo injection by Fe-Nano, Fe-Nano-Alimet chelate, Fe-Aliment chelate and Fe-Aliment chelate on hatchability traits

Table (1) shows the egg performance when injected with different forms of supplementary Iron. . There was a significant difference $(\mathrm{P}<0.01)$ between control and sham control with respect to hatchability percent. There seem to be a need for $\mathrm{NaCl}$ solution because of a deficiency of this mineral in the egg, which might explain the positive effect of saline injection. Sodium chloride is a mineral salt and it seemed to close a gap in the requirements of egg growth to this mineral. It might also have a positive effect with respect to buffering the medium inside the egg, which led to facilitating the growth performance, livelihood of the embryo and therefore the hatchability percent improved as a result. It seems that these explanations are logic since there was no significant difference between sham control (saline solution injection) and injection of different forms of Iron either as in nano particle form or not and the form of being organic or inorganic. The different forms of Iron in nano particle or in the organic or inorganic forms showed the same significant difference as the saline solution injection did. The same explanations might, therefore, apply. The check weight/egg weight ratio of control and sham control were not significantly different (74.5 and 74.8 for control and sham control, respectively). The injection of different forms of Iron positively enhanced this ratio. The ratios were $85.2,4.6$ and 84.4 for T3, T4 and T5, respectively).The inorganic form of
Iron (T6) was similar to both controls. Saki et al. (2014) found no significant effects on hatchability percent among the groups fed 50 and $150 \mathrm{ppm}$ Fe-Aliment chelate relative to control one. This may be explained by the deficiencies or excesses of individual trace elements that can cause impaired growth, abnormal development, thus, affecting all of the major organ systems and in extreme cases, death of the embryo (Richards and Steele, 1987). Appropriate amounts of each trace element are required to support embryonic growth and development, Richards, (1989). In mammals, Fe link to amino acids increased the transfer of $\mathrm{Fe}$ across the placenta and into the embryo, Ashamead and Graff, (1982).

The form of nano $\mathrm{Fe}$ in any form depends on the presence of protein and it would be interesting to investigate the relationship between protein and $\mathrm{Fe}$ atoms. Foye, et al., (2006) found that $\mathrm{Fe}$ atoms adhered easily to protein and that the co-existing system of protein and iron could directly scavenge $\mathrm{ROS}(\mathrm{OH} \bullet, \mathrm{O} \bullet-2$ and $\mathrm{H} 2 \mathrm{O} 2)$. Nano-particles can evade conventional physiological ways of nutrient distribution and transport across tissue and cell membranes, as well as protect compounds against destruction prior to reaching their targets. In-ovo administration of nanoparticles, may be seen as a new method of nano-nutrition, providing embryos with an additional quantity of nutrients.

\section{Growth performance at 7 day of age:}

Effects of in-ovo injection of nano forms of $\mathrm{Fe}$ Nano particles (either organic or inorganic) on average weight gain and feed efficiency ratio of broiler during the first week of age are shown in table (2). Body weight (gm) values during the first week gradually increased significantly $(\mathrm{P}<0.01)$. The control group showed the lowest body weight over the period of first seven day period (90.55 gm). Sham control showed higher significant body weight (120.5 gm) over this period compared to regular control. It was lower than the treatment of the injection of nano-Iron in either form (132.4 and $123.9 \mathrm{gm}$ for $\mathrm{T} 3$ and $\mathrm{T} 4$, respectively). The injection of regular $\mathrm{Fe}$ salt in both forms (organic and inorganic) showed lower (105.99 and 118.9 gm for organic and inorganic forms of regular $\mathrm{Fe}$ injection, respectively) body weight than both controls. Therefore, the percent increments of T2, T3 and T4 were 33.68, 46.26 and 36.83\%, compared to T1, respectively. Therefore, the weight gains of $\mathrm{T} 2$, T3 and T6 were significantly $(\mathrm{P}<0.01)$ higher compared to other treatments. They increased by $65.69,65.69$ and $58.01 \%$ than T1. With regard to feed intake, T2, T3, T4 increased by $59.03,37.9,6.19 \%$, respectively, than that of the $\mathrm{T} 1$ control. Results of feed conversion ratio ( $\mathrm{gm}$ feed/gm gain) revealed a highly significant difference $(\mathrm{P}<0.01)$ among the experimental treatments $(97.75,155.45,134.8$, 103.8, 112.75, and 155.75 for $\mathrm{T} 1, \mathrm{~T} 2, \mathrm{~T} 3, \mathrm{~T} 4, \mathrm{~T} 5$ and $\mathrm{T} 6$, 
respectively). It is observed that $\mathrm{T} 3, \mathrm{~T} 4, \mathrm{~T} 2$ and $\mathrm{T} 5$ recorded the best FCR and this may be due to the increase in feed intake and reduction of daily weight gain. This explained was introduced byFoye, et al., (2006) who noted that, in-ovo injection could lead to improved digestive capacity, increased growth rate and feed efficiency. Uni.et al., 2005 and Foye, et al., (2006) reported that the breast weight percentage was not significantly different among all treatments.

\section{Growth performance at 35 day of age:}

Effects of in-ovo injection by nano forms of $\mathrm{Fe}$ Nano particles on average weight gain and feed efficiency ratio of broiler during the experimental period (0-5 weeks of age) are shown in table (3). The weight gain (gm) of the T2, T3, T4, T5 and T6 (2101.94, 2118.94, 2124.6, 2049.67 and $2003.47 \mathrm{gm}$, respectively) significantly $(\mathrm{P}<0.05)$ increased than T1 (1855.23 gm). They increased by $13.29,14.2,10.27$ and $10.48 \%$ than $\mathrm{T} 1$. It is clear that $\mathrm{T} 2, \mathrm{~T} 3, \mathrm{~T} 4$ were increased feed intake by $21.43,15.03,2.45$ and $3.38 \%$, respectively, than that of the $\mathrm{T} 1$ treatment. Results of feed conversion ratio (FCR) (gm feed/gm gain) revealed a significant difference $(\mathrm{P}<0.01)$ among the experimental treatments. It was monitored in this study, that T2, T3, T4, T5 and T6 recorded the best FCR; these results match up the increase in feed intake and reduction of daily weight gain.

\section{Blood analysis.}

The effects of in-ovo injection of broiler eggs on plasma iron definitions in chicks on 35day of age are shown in Table (4). The results indicate that the effect of in-ovo injection of broiler eggs with nano forms of Fe-Nano, Fe-NPs-Alimet chelate, Fe-Aliment chelate and Fe-Aliment chelate recorded significant increased $(\mathrm{P}<0.01)$ the values of WBC's, HGB, MCHC and HCT, while it was insignificant in RBC's and MCV , MCH, RDWCV and RDWSD compared to control treatment (Table 3).

On the other view, it was found through the results in table 4 that the iron injection significantly $(\mathrm{P}<0.01)$ enhanced different blood parameters for $\mathrm{T} 2$ and $\mathrm{T} 1$ compared to other treatment (T3, T4, T5 and T6). Which the reduction value were $25.72,40.7,57.76,32.63$ and $30.5 \%$ compared to $\mathrm{T} 1$, respectively. There were significant $(\mathrm{P}<0.01)$ decrease in T2, T3, T4, T5 and T6 in TIBC. This decrease were by 47.8, 97.89. 84.6, 3.86\%, respectively. The same trend was observed in feretin, where there were significant deferent between T2, T3, T4 and T5 compere to T1 (by 49.45, 49.12, 33.42 and $37.87 \%$, respectively). This data was synchronized with the data showed of hematological parameters in table 3, especially in RBC's, Hb and HTC.
The treatments 25 ppm Fe-NPs, 100 ppm Fe-NPsAlimet chelate and $150 \mathrm{ppm}$ Fe-Alimet chelate have shown higher Fe content in serum and liver compared with those in other treatments. Seoet al. (2008) concluded that iron content of broiler meat could be effectively enriched by supplementation of $200 \mathrm{ppm}$ of $\mathrm{Fe}$ as Fe-Aliment chelate for 5 weeks. The results was demonstrated iron concentrations in the liver and kidney (Bertechini, et al., 2012) and chickens for fattening (Shinde, et al., 2011).The greatest mean increase was $+22 \%$ and $+31.9 \%$ for broiler muscle and liver, respectively. In addition, hemoglobin in two treatments of 100-ppm Fe-NPs- Alimet chelate and150-ppmFe-Alimet chelate significantly increased compared with other treatments.

The results of Warner et.al. (2006) indicated that the absolute amount of iron per liver increased steadily up to hatching time. Their results showed that the highest liver weight was observed in treatment having 25 ppm of Fe-NPs. The treatments 25 ppm Fe-Nano, 100 ppm Fe-NPs-Alimet chelate and 150 ppm Fe-Alimet chelate have shown higher Fe content in serum and liver compared with those in other treatments.

Effects of in-ovo injection on broiler eggs on plasma iron definitions in chicks on 35 day of age are shown in Table (5) .The data showed major variations in TP for T1, T2, T3 and T5 compared to T4 and T6, where, they were increased by $(11.8,12.57$ and $2.96 \%)$ related to $\mathrm{T} 1$, while the lowest value was for T6 (by $1.97 \%$ ) and no significant difference. The same trend was observed in $A, G$ and $A / G$ ratio. Since the albumen is synthesized mainly in liver, that liver function was enhanced by the injection of Iron in its different forms, and that the albumin is a main source for amino acid formation, the protein synthesis increased leading to more formation of muscles, which in turn leads to increased final body weight. This is clearly manifested in the results obtained in this study (Table 3 ).

\section{CONCLUSION}

These results suggest that under semi-arid conditions, the in-ovo injection of 20-ppm iron nanoparticles (Fe-NPs), 20-ppm iron nanoparticles Alimet chelate (FeNPs-Alimet chelate) and 20-ppm Fe-Alimet chelate as injection contributed to embryonic growth development. Iron nanoparticles and Alimet chelate form, as the active in gradient of feed additives, premixes, and compound feed, due to the high surface activity and penetration into cell can actively influence the intracellular metabolism by stimulating various processes. 
The nano form of $\mathrm{Fe}$ are not harmful to the embryo (injected with $20 \mathrm{ppm}$ ) and can be used to improve the posthatch performance of broiler.

\section{REFERENCES}

[1] Agarwal A, Saleh RA, Bedaiwy MA (2003). Role of reactive oxygen species in the pathophysiology of human reproduction. Fertility and sterility. 79(4):82943.

[2] Aitken RJ. (1995). Free radicals, lipid peroxidation and sperm function. Reproduction, Fertility and Development. 7(4):659-68.

[3] Ashmead, H.D. and D.J. Graff (1982): Placental transfer of chelated iron. Proceeding of the International Pig, Veterinary Society Congress, Mexico. pp. 207.

[4] Baumber J, Ball BA, Gravance CG, Medina V, DaviesMorel M (2012). The effect of reactive oxygen species on equine sperm motility, viability, acrosomal integrity, mitochondrial membrane potential, and membrane lipid peroxidation. Journal of andrology. 21(6):895-902.

[5] Bertechini, A. E. J. Fassani, J.A. Gonçalves de Brito and P. R. Barrios (2012): RevistaBrasileira de Zootechnica., Vol. 41, pp.624-629.

[6] Bronstein, LM.X. Huang, J. Retrum, A. Schumacher, M. Pink, B.D (2007).Stein and B .Dragnea: Chem Materials., Vol.19, No.15, (2007), pp.36243632.

[7] Buzea C, Pacheco II, Robbie K (2007). Nanomaterials and nanoparticles: sources and toxicity. Bio interphases. 2007; 2(4). 13.

[8] Chen S, Zhao Y, Zhao G, Han W, Bao L, Yu K, et al. (2009). Up-regulation of ROS by mitochondriadependent bystander signaling contributes to genotoxicity of bystander effects. Mutation Research/Fundamental and Molecular Mechanisms of Mutagenesis. 666(1):68-73.

[9] Chen Y-C, Hsiao J-K, Liu H-M, Lai I-Y, Yao M, Hsu S-C, et al. (2010).The inhibitory effect of super paramagnetic iron oxide nanoparticle (Ferucarbotran) on estrogenic differentiation and its signaling mechanism in human mesenchymal stem cells. Toxicology and Applied Pharmacology. 245(2):272-9.

[10] Cronwright G, Le Blanc K, Götherström C, Darcy P, Ehnman M, Brodin B (2005). Cancer/testis antigen expression in human mesenchymal stem cells: downregulation of SSX impairs cell migration and matrix metalloproteinase 2 expression. Cancer Research. 65(6):2207-15

[11] Das M, Patil S, Bhargava N, Kang J-F, Riedel LM, Seal S, et al. (2007). Auto-catalytic ceria nanoparticles offer neuroprotection to adult rat spinal cord neurons. Biomaterials. 28 (10):1918-25.

[12] DimanRahmatollah, AmjadFarzinpour, AsaadVaziry\&GhorbanaliSadeghi (2018)..Effect of replacing dietary $\mathrm{FeSO} 4$ with cysteinecoated $\mathrm{Fe} 3 \mathrm{O} 4$ nanoparticles on quails. Italian Journal of Animal Science. 2018 VOL. 17, NO. 1, 121-127

[13]Duncan, D. B., 1955. Multiple ranges and multiple Ftest.

[14]Feng, J.W.Q. Ma, Z.R. Xu, J.X. He, Y.Z. Wang and J.X. Liu (2009): Anim Feed Sci Technol., Vol.150, pp. 106-113.

[15]Foye O.T., Z. Uni and P.R. Ferket (2006): Poult Sci., Vol.85, pp.1185-1192.

[16] Gao L, Zhuang J, Nie L, Zhang J, Zhang Y, Gu N, et al (2007). Intrinsic peroxidase-like activity of ferromagnetic nanoparticles. Nature nanotechnology. 2 (9): 577-83.

[17] Kovalenko L.V. and G.E. Folmanis (2006): Biologic heskiaktivnyenanoporoshki zheleza (Biologically Active Iron Nano powders), Moscow: Nauka..

[18]Li, M., and C. Zhao, (2009): Study on Tibet a chicken embryonic adaptability to chronic hypoxia by revealing differential gene expression in heart tissue. Sci. China C. Life Sci. 52, 284-295.

[19]Lozoff, B., N. Kaci rot, and T. Walter, (2006): Iron deficiency in infancy: Applying a physiologic framework for prediction. Am. J. Clin. Nutr. 84, 14121421.

[20] Ma, Y., Yeh, M., Yeh, K. Y., and Glass, J (2006). Iron imports. V. Transport of iron through the intestinal epithelium. Am. J. Physiol. Gastro. L. 290, G417G422.

[21] Marinescu, G.L. Patron, D.C. Culita, C. Neagoe, C.I. Lepadatu, I. Balint, L. Bessais and C.B.Cizmas (2006). Synthesis of magnetite nanoparticles in the presence of amino acids. J NanoparticleRes.,Vol.8,pp.1045-1051.

[22] Nel, A. T. Xia and L. Madler (2006): Toxic Potential of Materials at the NanolevelSci., Vol. 311, (2006), pp. 622-627.

[23] Nikonov I. N., Folmanisb Yu. G., Folmanisb G. E., Kovalenkob L. V., Lapteva G. Yu, EgorovcFisininc I. A., V. I., and. Tananaevd I. G.,( 2012). Iron Nanoparticles as a Food Additive for Poultry. Doklady Biological Sciences Vol. 440.

[24]NRC. (1994). Nutrient Requirements of Poultry. National Academy Press, Washington, DC. USA. p.27.

[25] Oberdorster, G., V. Stone and K. Donaldson (2007): J Nano toxicology, Vol.1, pp. 2-25. 
[26] Park E-J, Kim H, Kim Y, Park K (2010). Effects of platinum nanoparticles on the postnatal development of mouse pups by maternal exposure. Environmental Health and Toxicology. 2010; 25(4):279-86.

[27] Parke D, Sapota A (1996). Chemical toxicity and reactive oxygen species. International journal of occupational medicine and environmental health. 9(4):331-40.

[28] Predieri, G.L. Elviri, M. Tegoni, I. Zagnoni, E. Cinti, G. Biagi, S. Ferruzza and G. Leonardi (2005). J. Inorganic Biochem. Vol.99, pp.627-636.

[29] Reimers, G.W and S.E. Khalafalla (1974): Production of Magnetic Fluids by Peptization Techniques. US Patent No. 3843540.

[30] Richards, M.P, and N.C. Steele (1989): Serum corticosterone concentrations in developing shell-less and shelled turkey embryos. J ExptlZool, Suppl.Vol.1, pp.39-51.

[31] Richards, M.P. (1989). Influence of egg production on zinc, copper and iron metabolism in the turkey hen (Meleagrisgallopavo). Comp. Biochem Physiol., Vol.93A, pp.811-817.

[32] Romanoff, AJ. (1960): The Avian Embryo. Macmillan, New York, NY.

[33] Saki AA, Abbasinezhad M, Rafati AA. 2014. Iron nanoparticles and methionine hydroxy analogue chelate in ovo feeding of broiler chickens. Int $\mathbf{J}$ NanosciNanotechnol. 10:187-196.

[34] SAS, 2002. SAS/STAT User, S Guide: Statistics. Ver. 8.2, SAS Institute Inc., Cary. NC.

[35] Scott, N.R and H. Chen (2002): Nanoscale Science and Engineering for Agriculture and Food Systems. National PlanningNational planning. Workshop, www.nseafs.cornell.edu.

[36] Seo, S.H., H.K. Lee, W.S. Lee, K.S. Shin and I.K. Paik (2008):The Effect of Level and Period of Fe-methionine Chelate Supplementation on the Iron Content of Boiler Meat Asian-Austr J Anim Sci., Vol. 21, No.10, pp.1501-1505.

[37] Shimizu M, Tainaka H, Oba T, Mizuo K, Umezawa M, Takeda K (2009). Maternal exposure to Nano particulate titanium dioxide during the prenatal period alters gene expression related to brain development in the mouse. Part FibreToxicol. 6(20):20-1.

[38] Shinde, P.L, S.L. Ingale, J.Y. Choi, J.S. Kim, S.I. Pak and B. J. Chae (2011): Br Poult Sci., Vol. 52, pp.578583.
[39] Singh N, Manshian B, Jenkins G, Griffiths SM, Williams PM, Maffeis $T$, et al (2009). Nano Genotoxicology: the DNA damaging potential of engineered nanomaterials. Biomaterials. 30(2324):3891-914.

[40] Tako, E., Rutzke, M.A. \&Glahn, R.P. (2010) Using the domestic chicken (Gallus gallus) as an in vivo model for iron bioavailability. Poultry Sci. 89, 514-521.

[41] Tona. K., O. M. Onagbesan, Y. Jego, B. Kamers, E. Decuypere, and V. Bruggeman.(2004). Comparison of embryo physiological parameters during incubation, chick quality, and growth performance of three lines of broiler breeders differing in genetic composition and growth rate. Poult. Sci.83:507513

[42] Toyooka T, Amano T, Suzuki H, Ibuki Y (2009). DNA can sediment Tio2 particles and decrease the uptake potential by mammalian cells. Science of the Total Environment. 407 (7):2143-50.

[43] Uni, Z., P.R. Ferket, E. Tako, O. and Kedar, (2005): In Ovo, Feeding Improves Energy Status of Late-Term Chicken Embryos. Poultry Science. 84, 764-770

[44] Wang F, Gao F, Lan M, Yuan H, Huang Y, Liu J (2009). Oxidative stress contributes to silica nanoparticle-induced cytotoxicity in human embryonic kidney cells. Toxicology in vitro. 2009; 23 (5):808-15.

[45] Wang J, Zhou G, Chen C, Yu H, Wang T, Ma Y, et al. (2007). Acute toxicity and bio-distribution of different sized titanium dioxide particles in mice after oral administration. Toxicology letters. 168(2):176-85.

[46] Warheit DB (2008). How meaningful are the results of nano toxicity studies in the absence of adequate material characterization? Toxicological Sciences. 101(2):183-5

[47] Warner, J. D., P.R. Ferket, V. L. Christensen and J. V. Felts (2006). Effect of season, hatch time, and posthatch holding on glycogen status of turkey poults. Poult Sci., Vol. 85, (Suppl.1), (2006), 117 (Abstr.)

[48] Warner, J.D and Ferket, V.L (2006). Christensen and J. V. Felts: Poult Sci., Vol. 85, (Suppl.1), 117, (Abstr.).

[49] Whitnall, M., and D.R. Richardson, (2006): Iron: A new target for pharmacological intervention in neurodegenerative diseases. Seminars Pediatric Neurol. 13, 186-197.

[50]Zong W.X., Thompson C.B. (2006). Necrotic death as a cell fate. Genes \& development. 20(1):1-15. 
Table.1: $\quad$ Mean \pm SE of egg weight, checks hatching weight, ratio between egg and checks weights and hatchability percent as affected byiIn ovoinjection

\begin{tabular}{|c|c|c|c|c|}
\hline Items & $\begin{array}{c}\text { Egg weight } \\
(\mathrm{g})\end{array}$ & $\begin{array}{c}\text { Hatch weight of } \\
\text { chicks }(\mathrm{g})\end{array}$ & $\begin{array}{c}\text { Ratio between chicks } \\
\text { weight to egg weight } \%\end{array}$ & Hatchability \% \\
\hline T1 & $60.83^{\mathrm{a}} \pm 0.80$ & $45.32^{\mathrm{b}} \pm 0.80$ & $74.52^{\mathrm{b}} \pm 0.78$ & $92.01^{\mathrm{b}} \pm 4.11$ \\
\hline T2 & $60.81^{\mathrm{a}} \pm 0.79$ & $48.56^{\mathrm{ab}} \pm 0.75$ & $74.81^{\mathrm{b}} \pm 0.90$ & $96.36^{\mathrm{a}} \pm 3.08$ \\
\hline T3 & $60.91^{\mathrm{a}} \pm 0.78$ & $51.90^{\mathrm{a}} \pm 0.94$ & $85.22^{\mathrm{a}} \pm 1.02$ & $95.05^{\mathrm{a}} \pm 2.15$ \\
\hline T4 & $60.81^{\mathrm{a}} \pm 0.79$ & $51.43^{\mathrm{a}} \pm 0.77$ & $84.58^{\mathrm{a}} \pm 0.83$ & $94.21^{\mathrm{a}} \pm 3.57$ \\
\hline T5 & $60.80^{\mathrm{a}} \pm 0.91$ & $51.33^{\mathrm{a}} \pm 0.84$ & $84.42^{\mathrm{a}} \pm 0.90$ & $95.15^{\mathrm{a}} \pm 2.5$ \\
\hline T6 & $60.82^{\mathrm{a}} \pm 0.91$ & $47.43^{\mathrm{b}} \pm 0.77$ & $77.88^{\mathrm{ab}} \pm 0.90$ & $94.92^{\mathrm{a}} \pm 0.90$ \\
\hline Sig. & n. s & $*$ & $*$ & $*$ \\
\hline
\end{tabular}

a, b: Means within a column with different superscripts are significantly different $(\mathrm{P}<0.01)$.

Sig. $=$ Significance, $*(\mathrm{P}<0.01), \mathrm{n} . \mathrm{s}=$ not significant.

Table.2: Effect of ovov injection on broiler eggs on final weight, weight gain, feed intake and feed efficiency ratio at 7 day of age

\begin{tabular}{|c|c|c|c|c|c|}
\hline Items & $\begin{array}{c}\text { Chick } \\
\text { Weight }(\mathrm{g})\end{array}$ & Body weight $(\mathrm{g})$ & $\begin{array}{c}\text { Weight gain } \\
(\mathrm{g} / \text { period })\end{array}$ & $\begin{array}{c}\text { Feed intake } \\
(\mathrm{g} / \text { period })\end{array}$ & $\begin{array}{c}\text { Feed } \\
\text { conversion ratio }\end{array}$ \\
\hline T1 & $45.32^{\mathrm{c}} \pm 0.80$ & $90.55^{\mathrm{c}} \pm 22.82$ & $45.23^{\mathrm{b}} \pm 21.89$ & $97.75^{\mathrm{c}} \pm 28.22$ & $2.15^{\mathrm{c}} \pm 0.09$ \\
\hline T2 & $48.56^{\mathrm{a}} \pm 0.75$ & $120.50^{\mathrm{a}} \pm 24.55$ & $74.94^{\mathrm{a}} \pm 23.08$ & $155.45^{\mathrm{a}} \pm 30.01$ & $2.08^{\mathrm{b}} \pm 0.17$ \\
\hline T3 & $51.90^{\mathrm{a}} \pm 0.94$ & $132.44^{\mathrm{a}} \pm 26.78$ & $74.94^{\mathrm{a}} \pm 25.66$ & $134.80^{\mathrm{a}} \pm 32.05$ & $1.80^{\mathrm{a}} \pm 0.24$ \\
\hline T4 & $51.43^{\mathrm{a}} \pm 0.77$ & $123.90^{\mathrm{ab}} \pm 25.91$ & $54.67^{\mathrm{b}} \pm 26.14$ & $103.8^{\mathrm{a}} \pm 27.08$ & $1.89^{\mathrm{a}} \pm 0.11$ \\
\hline T5 & $51.33^{\mathrm{a}} \pm 0.84$ & $105.99^{\mathrm{b}} \pm 25.91$ & $54.67^{\mathrm{b}} \pm 24.14$ & $112.75 \mathrm{a}^{\mathrm{b}} \pm 29.23$ & $2.05^{\mathrm{b}} \pm 0.17$ \\
\hline T6 & $47.43^{\mathrm{b}} \pm 0.7$ & $118.90^{\mathrm{b}} \pm 25.91$ & $71.47^{\mathrm{b}} \pm 25.14$ & $155.75^{\mathrm{ab}} \pm 27.25$ & $2.18^{\mathrm{bc}} \pm 0.17$ \\
\hline Sig. & $*$ & $*$ & $*$ & $*$ & $*$ \\
\hline
\end{tabular}

a,b: Means within a column with different superscripts are significantly different $(\mathrm{P}<0.01)$.

Sig. = Significance, $*(\mathrm{P}<0.01), \mathrm{n} . \mathrm{s}=$ not significant

Table.3: The effect of ovo injection of broiler on final weight, weight gain, feed intake and feed efficiency ratio at 35 day of age.

\begin{tabular}{|c|c|c|c|c|c|}
\hline Items & $\begin{array}{c}\text { Chick } \\
\text { Weight (g) }\end{array}$ & $\begin{array}{c}\text { Body weight } \\
(\mathrm{g})\end{array}$ & $\begin{array}{l}\text { Weight gain } \\
\text { (g/period) }\end{array}$ & $\begin{array}{c}\text { Feed intake } \\
(\mathrm{g} / \text { period })\end{array}$ & $\begin{array}{c}\text { Feed } \\
\text { conversion ratio }\end{array}$ \\
\hline $\mathrm{T} 1$ & $45.32^{c} \pm 0.80$ & $1900.5^{b} \pm 22.82$ & $1855.23^{b} \pm 21.89$ & $3691.75^{\mathrm{c}} \pm 28.22$ & $1.99^{\mathrm{a}} \pm 0.09$ \\
\hline $\mathrm{T} 2$ & $\begin{array}{l}\quad 48.56^{\mathrm{ab}} \\
\pm 0.75\end{array}$ & ${ }_{5} 2150.50^{\mathrm{a}} \pm 24.5$ & $2101.94^{\mathrm{a}} \pm 23.08$ & $2900.45^{\mathrm{a}} \pm 30.01$ & $1.38^{\mathrm{b}} \pm 0.17$ \\
\hline $\mathrm{T} 3$ & $\begin{array}{l}51.90^{\mathrm{a}} \pm \\
0.94\end{array}$ & $8^{2170.44^{\mathrm{a}} \pm 26.7}$ & $2118.94^{\mathrm{a}} \pm 25.66$ & $3136.80^{\mathrm{a}} \pm 32.05$ & $1.48^{\mathrm{b}} \pm 0.24$ \\
\hline $\mathrm{T} 4$ & $\begin{array}{l}51.43^{\mathrm{a}} \pm 0.7 \\
7\end{array}$ & ${ }_{1}^{2175.90^{\mathrm{a}} \pm 25.9}$ & $2124.67^{\mathrm{a}} \pm 26.14$ & $3059.8^{\mathrm{a}} \pm 27.08$ & $1.44^{\mathrm{b}} \pm 0.11$ \\
\hline T5 & $51.33^{\mathrm{a}} \pm 0.84$ & $\begin{array}{l}2100.99^{\mathrm{ab}} \pm 25.9 \\
1\end{array}$ & $2049.67^{\mathrm{ab}} \pm 24.14$ & $3566.75^{\mathrm{ab}} \pm 29.23$ & $1.74^{\mathrm{ab}} \pm 0.09$ \\
\hline T6 & $47.43^{\mathrm{b}} \pm 0.70$ & $\begin{array}{l}2050.90^{\mathrm{ab}} \pm 25.9 \\
1\end{array}$ & $2003.47^{\mathrm{ab}} \pm 25.14$ & $3766.75^{\mathrm{ab}} \pm 27.25$ & $1.88^{\mathrm{ab}} \pm 0.17$ \\
\hline Sig. & $*$ & $*$ & $*$ & $*$ & $*$ \\
\hline
\end{tabular}

a, b, c: Means within a column with different superscripts are significantly different $(\mathrm{P}<0.01)$.

Sig.= Significance, ${ }^{* *}(\mathrm{P}<0.01), \mathrm{n} . \mathrm{s}=$ not significant 
Table.4: Effect of ovo injection on broiler eggs on plasma iron definitions in chicks on 35 day of age.

\begin{tabular}{|c|c|c|c|c|c|c|}
\hline TR & $\mathrm{T} 1$ & $\mathrm{~T} 2$ & T3 & $\mathrm{T} 4$ & $\mathrm{~T} 5$ & T6 \\
\hline $\begin{array}{l}\text { WBCS } \\
\left(10^{9} / 1\right)\end{array}$ & $108.70^{\mathrm{b}} \pm 8.45$ & $144.77^{\mathrm{a}} \pm 9.55$ & $142.33^{\mathrm{a}} \pm 8.24$ & $104.23^{\mathrm{b}} \pm 7.99$ & $121.27^{\mathrm{ab}} \pm 7.85$ & $113.33^{\mathrm{b}} \pm 10.00$ \\
\hline $\mathrm{L} 1 \%$ & $60.00^{\mathrm{ab}} \pm 2.20$ & $60.00^{\mathrm{ab}} \pm 2.30$ & $61.33^{\mathrm{a}} \pm 2.40$ & $52.00^{c} \pm 2.00$ & $56.67^{\mathrm{abc}} \pm 2.33$ & $59.67^{\mathrm{ab}} \pm 2.22$ \\
\hline $\mathrm{N} 1 \%$ & $31.67^{\mathrm{abc}} \pm 1.96$ & $31.67^{\mathrm{abc}} \pm 2.01$ & $29.67^{c} \pm 1.92$ & $38.00^{\mathrm{a}} \pm 2.12$ & $35.33^{\mathrm{abc}} \pm 1.89$ & $30.33^{b c} \pm 1.89$ \\
\hline M1\% & $5.00^{a} \pm 0.45$ & $5.00^{\mathrm{a}} \pm 0.51$ & $5.33^{\mathrm{a}} \pm 0.53$ & $6.00^{\mathrm{a}} \pm 0.49$ & $5.00^{\mathrm{a}} \pm 0.60$ & $6.00^{\mathrm{a}} \pm 0.44$ \\
\hline $\mathrm{E} 1 \%$ & $3.33^{\mathrm{a}} \pm 0.50$ & $3.33^{\mathrm{a}} \pm 0.61$ & $3.67^{\mathrm{a}} \pm 0.61$ & $4.00^{\mathrm{a}} \pm 0.55$ & $3.00^{\mathrm{a}} \pm 0.70$ & $4.00^{\mathrm{a}} \pm 0.50$ \\
\hline $\begin{array}{l}\mathrm{HB} \\
(\mathrm{g} / \mathrm{l})\end{array}$ & $10.60^{\mathrm{a}} \pm 0.65$ & $11.57^{\mathrm{a}} \pm 2.30$ & $10.27^{\mathrm{a}} \pm 1.85$ & $10.70^{\mathrm{a}} \pm 1.45$ & $10.37^{\mathrm{a}} \pm 2.61$ & $10.60^{\mathrm{a}} \pm 1.35$ \\
\hline $\begin{array}{r}\text { RBCS } \\
\left(10 /{ }^{6} \mu \mathrm{l}\right)\end{array}$ & $3.12^{\mathrm{a}} \pm 0.38$ & $2.78^{\mathrm{a}} \pm 0.21$ & $2.94^{\mathrm{a}} \pm 0.29$ & $2.44^{\mathrm{a}} \pm 0.19$ & $2.56^{\mathrm{a}} \pm 0.20$ & $3.09^{\mathrm{a}} \pm 0.33$ \\
\hline НСТ \% & $34.80^{\mathrm{a}} \pm 4.16$ & $35.50^{\mathrm{a}} \pm 5.56$ & $35.30^{\mathrm{a}} \pm 3.96$ & $31.67^{\mathrm{a}} \pm 4.47$ & $31.30^{\mathrm{a}} \pm 6.12$ & $34.27^{\mathrm{a}} \pm 6.32$ \\
\hline $\begin{array}{c}\mathrm{MCV} \\
(\mu \mathrm{m}, \mathrm{fl})\end{array}$ & $90.63^{b} \pm 8.52$ & $127.53^{\mathrm{a}} \pm 9.18$ & $121.67^{\mathrm{a}} \pm 12.25$ & $119.67^{\mathrm{a}} \pm 10.25$ & $122.00^{\mathrm{a}} \pm 9.98$ & $82.33^{\mathrm{b}} \pm 14.59$ \\
\hline $\begin{array}{l}\mathrm{MCH} \\
(\mathrm{pg})\end{array}$ & $35.67^{\mathrm{ab}} \pm 5.52$ & $44.13^{\mathrm{a}} \pm 6.72$ & $38.87^{\mathrm{a}} \pm 4.56$ & $38.57^{\mathrm{a}} \pm 4.95$ & $39.57^{\mathrm{a}} \pm 4.04$ & $29.63 b^{c} \pm 6.07$ \\
\hline $\begin{array}{l}\text { MCHC } \\
(\mu \mathrm{m}, \mathrm{fl})\end{array}$ & $30.90^{\mathrm{ab}} \pm 6.42$ & $32.30^{\mathrm{ab}} \pm 4.12$ & $30.37^{\mathrm{ab}} \pm 4.25$ & $29.67^{\mathrm{b}} \pm 5.21$ & $32.53^{\mathrm{ab}} \pm 5.51$ & $33.63^{\mathrm{a}} \pm 4.95$ \\
\hline $\mathrm{V}^{\mathrm{RDW}+\mathrm{C}}$ & $15.23^{\mathrm{a}} \pm 0.91$ & $12.17^{\mathrm{b}} \pm 0.74$ & $15.50^{\mathrm{a}} \pm 0.81$ & $14.97^{\mathrm{a}} \pm 0.81$ & $15.50^{\mathrm{a}} \pm 0.84$ & $15.50^{\mathrm{a}} \pm 0.75$ \\
\hline $\begin{array}{l}\text { RDW_S } \\
\mathrm{D}\end{array}$ & $33.37^{\mathrm{a}} \pm 4.01$ & $45.97^{\mathrm{a}} \pm 3.85$ & $37.93^{\mathrm{a}} \pm 4.13$ & $40.53^{\mathrm{a}} \pm 3.95$ & $34.70^{\mathrm{a}} \pm 4.21$ & $37.93^{\mathrm{a}} \pm 4.00$ \\
\hline
\end{tabular}

a, b, c Means within the same row with no common superscript differ significantly.

$* * \mathrm{P} \leq 0.01, \mathrm{NS}=$ non-significant

Table.5: Effect of ovo injection on broiler eggs on plasma iron definitions in chicks on 35 day of age.

\begin{tabular}{|l|r|r|r|r|r|r|}
\hline TR & \multicolumn{1}{|c|}{ T1 } & \multicolumn{1}{|c|}{ T2 } & \multicolumn{1}{l|}{ T4 } & \multicolumn{1}{l|}{ T5 } & \multicolumn{1}{c|}{ T6 } \\
\hline & $360.33^{\mathrm{a}} \pm$ & $267.67^{\mathrm{ab}} \pm$ & $213.67^{\mathrm{b}} \pm$ & $163.00^{\mathrm{b}} \pm$ & $180.33^{\mathrm{b}}$ & $147.33^{\mathrm{b}} \pm$ \\
Iron $(\mu \mathrm{g} / \mathrm{L})$ & 37.98 & 38.10 & 38.2 & 37.99 & \pm 38.22 & 38.15 \\
\hline TIBC $(\mu \mathrm{g} /$ & $158.00^{\mathrm{b}} \pm$ & $276.33^{\mathrm{a}} \pm$ & $312.67^{\mathrm{a}} \pm$ & $291.67^{\mathrm{a}} \pm$ & $276.00^{\mathrm{a}}$ & $343.67^{\mathrm{a}} \pm$ \\
$\mathrm{L})$ & 25.21 & 26.50 & 26.19 & 25.22 & \pm 26.19 & 25.21 \\
\hline Ferritin & $51.17^{\mathrm{ab}} \pm$ & $76.47^{\mathrm{a}} \pm$ & & $68.27^{\mathrm{ab}} \pm$ & $47.53^{\mathrm{ab}}$ & $40.20^{\mathrm{b}} \pm$ \\
$(\mu \mathrm{g} / \mathrm{L})$ & 9.77 & 10.02 & $76.30^{\mathrm{a}} \pm 9.99$ & 9.89 & \pm 9.94 & 10.10 \\
\hline
\end{tabular}

$\mathrm{a}, \mathrm{b}, \mathrm{c}$ Means within the same row with no common superscript differ significantly.

$* * \mathrm{P} \leq 0.01, \mathrm{NS}=$ non-significant

Table.6: Effect of ovo injection on broiler eggs on blood analysis at 35 day of age

\begin{tabular}{|c|c|c|c|c|c|c|}
\hline TR & T1 & T2 & T3 & T4 & T5 & T6 \\
\hline TP $(g / d L)$ & $2.73^{\mathrm{ab}} \pm 0.34$ & $3.05^{\mathrm{a}} \pm 0.40$ & $2.67^{\mathrm{ab}} \pm 0.39$ & $2.40^{\mathrm{b}} \pm 0.37$ & $2.96^{\mathrm{ab}} \pm 0.35$ & $2.99^{\mathrm{b}} \pm 0.39$ \\
\hline $\mathrm{Alb}(\mathrm{g} / \mathrm{dL})$ & $1.33^{\mathrm{ab}} \pm 0.18$ & $1.70^{\mathrm{a}} \pm 0.22$ & $1.50^{\mathrm{ab}} \pm 0.21$ & $1.35^{\mathrm{b}} \pm 0.20$ & $1.60^{\mathrm{ab}} \pm 0.19$ & $1.57^{\mathrm{ab}} \pm 0.18$ \\
\hline $\mathrm{Gl}(\mathrm{g} / \mathrm{dL})$ & $1.40^{\mathrm{a}} \pm 0.24$ & $1.35^{\mathrm{a}} \pm 0.21$ & $1.17^{\mathrm{b}} \pm 0.20$ & $1.05^{\mathrm{b}} \pm 0.25$ & $1.36^{\mathrm{a}} \pm 0.23$ & $1.42^{\mathrm{a}} \pm 0.22$ \\
\hline $\mathrm{A} / \mathrm{g}$ & $1.05^{\mathrm{ab}} \pm 1.01$ & $0.79^{\mathrm{a}} \pm 1.10$ & $0.78^{\mathrm{ab}} \pm 0.98$ & $0.78^{\mathrm{b}} \pm 0.99$ & $0.85^{\mathrm{ab}} \pm 1.99$ & $0.91^{\mathrm{a}} \pm 1.00$ \\
\hline ALT $(\mathrm{g} / \mathrm{dL})$ & $103.67^{\mathrm{a}} \pm 4.33$ & $135.67^{\mathrm{a}} \pm 3.90$ & $94.67^{\mathrm{b}} \pm 2.22$ & $84.33^{\mathrm{b}} \pm 2.22$ & $83.33^{\mathrm{b}} \pm 2.22$ & $75.67^{\mathrm{c}} \pm 4.97$ \\
\hline AST $(\mathrm{g} / \mathrm{dL})$ & $13.27^{\mathrm{a}} \pm 2.28$ & $14.17^{\mathrm{a}} \pm 1.80$ & $12.53^{\mathrm{a}} \pm 2.10$ & $13.50^{\mathrm{a}} \pm 1.90$ & $15.40^{\mathrm{a}} \pm 2.08$ & $14.40^{\mathrm{a}} \pm 1.98$ \\
\hline Urea $(\mathrm{g} / \mathrm{dL})$ & $12.33^{\mathrm{a}} \pm 1.57$ & $15.67^{\mathrm{a}} \pm 1.55$ & $13.00^{\mathrm{a}} \pm 1.45$ & $13.33^{\mathrm{a}} \pm 1.77$ & $14.33^{\mathrm{a}} \pm 1.65$ & $16.33^{\mathrm{a}} \pm 1.57$ \\
\hline
\end{tabular}




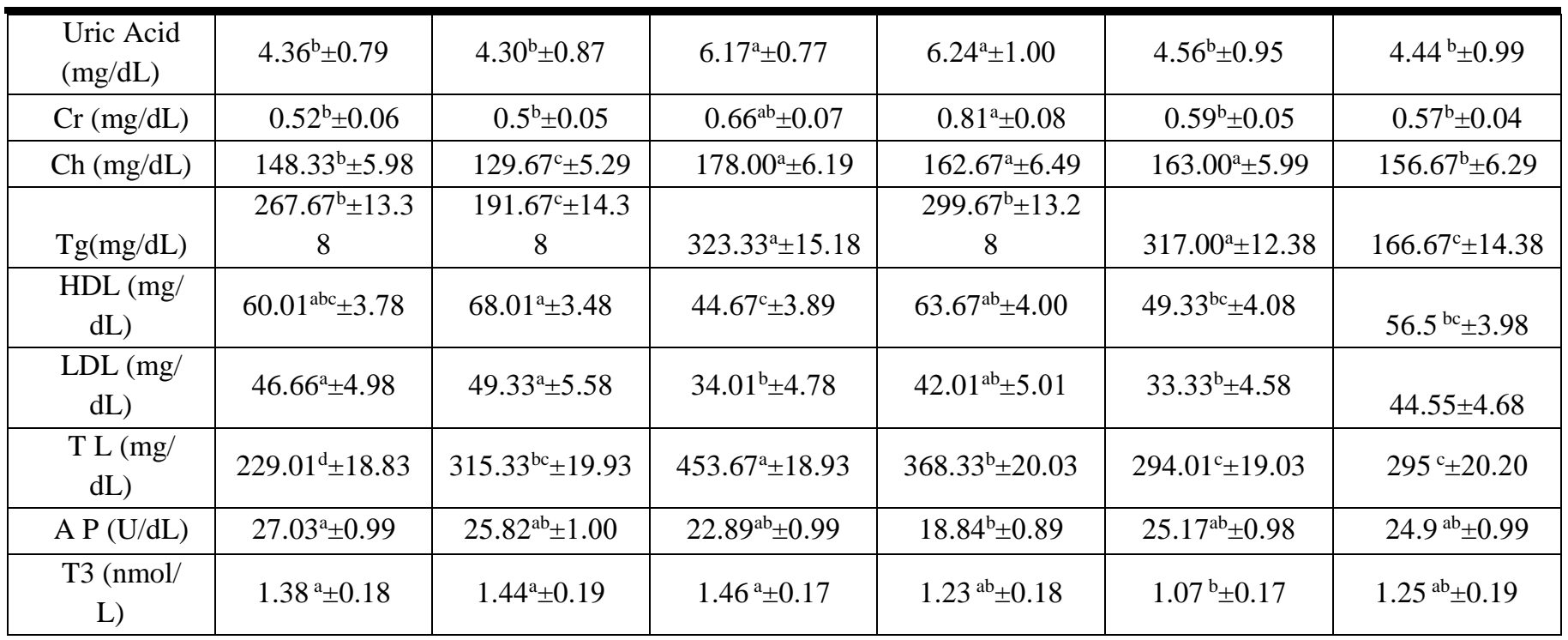

a, b, c Means within the same row with no common superscript differ significantly.

$* * \mathrm{P} \leq 0.01, \mathrm{NS}=$ non-significant 